indicate it as a suitable depository for individual works and collections. It is hoped that our members will bear it in mind whenever they may have books to dispose of.

The catalogued accessions in 1912 were 689 volumes. Through exchange of duplicates we have been able to fill several gaps in our sets of Journals. We now have Orelle complete from volume 68 to 141, and will soon have the Fortschritte complete from volume 1 to date. The McClintock gift included the first 20 volumes of the Quarterly Journal in continuous sequence. Still, many gaps will be noticed in the lists in the following pages of the Register, and the Librarian will be especially grateful to our members for any help in filling these.

The table below shows the growth of the Library during the past eleven years.

\begin{tabular}{|c|c|c|c|}
\hline & $\underset{1902 .}{\text { January } 1,}$ & $\underset{1907 .}{\text { January } 1,}$ & $\underset{1913 .}{\text { January } 1,}$ \\
\hline $\begin{array}{l}\text { Volumes of periodicals................. } \\
\text { Volumes, non-periodical.............. } \\
\text { Periodicals on exchange list .......... }\end{array}$ & $\begin{array}{l}32 \\
89 \\
64\end{array}$ & $\begin{array}{l}1,941 \\
608^{*} \\
167\end{array}$ & $\begin{array}{l}3352 \\
1,208^{*} \\
173\end{array}$ \\
\hline
\end{tabular}

NEW YoRk, December 26, 1912.

\title{
LIBRARY RULES
}

1. Applications for books may be made in person, or by letter addressed to the American Mathematical Society, 501 West 116th Street, New York. Members may, if they desire, apply in person directly to the superintendent of the loaning department of the Columbia University Library, where the Society's library is deposited. Books will be delivered directly to those applying in person, and will be sent to other applicants by express at the expense of the borrowers.

2. A book may be kept four weeks from the date of leaving the library, but the loan may be renewed from time to time by writing to the Society in advance of the day when the book is due.

3. Borrowers should return the books in person or by prepaid express.

* Exclusive of unbound dissertations. 